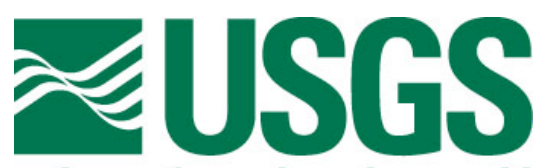

science for a changing world

\title{
Short Course Introduction to Quantitative Mineral Resource Assessments
}

By Donald A. Singer ${ }^{1}$

Open-File Report 2007-1434

2007

U.S. Deprtment of the Interior

U.S. Geological Survey

${ }^{1}$ U.S. Geological Survey, Menlo Park, Calif. 


\title{
U.S. Department of the Interior \\ DIRK KEMPTHORNE, Secretary
}

\author{
U.S. Geological Survey \\ Mark D. Myers, Director
}

U.S. Geological Survey, Reston, Virginia 2007

For product and ordering information:

World Wide Web: http://www.usgs.gov/pubprod

Telephone: 1-888-ASK-USGS

For more information on the USGS - the Federal source for science about the Earth, its natural and living resources, natural hazards, and the environment: World Wide Web: http://www.usgs.gov

Telephone: 1-888-ASK-USGS

Suggested citation:

Singer, Donald A., 2007, Short course introduction to quantitative mineral resource assessments: U.S. Geological Survey Open-File Report 20071434 [http://pubs.usgs.gov/of/2007/1434/].

Any use of trade, product, or firm names is for descriptive purposes only and does not imply endorsement by the U.S. Government.

Although this report is in the public domain, permission must be secured from the individual copyright owners to reproduce any copyrighted material contained within this report. 


\title{
Short Course Introduction to Quantitative Mineral Resource Assessments
}

\author{
By Donald A. Singer
}

This is an abbreviated text supplementing the content of three sets of slides used in a short course that has been presented by the author at several workshops. The slides should be viewed in the order of (1) Introduction and models, (2) Delineation and estimation, and (3) Combining estimates and summary. References cited in the slides are listed at the end of this text.

The purpose of the three-part form of mineral resource assessments discussed in the accompanying slides is to make unbiased quantitative assessments in a format needed in decision-support systems so that consequences of alternative courses of action can be examined. The three-part form of mineral resource assessments was developed to assist policy makers evaluate the consequences of alternative courses of action with respect to land use and mineral-resource development. The audience for three-part assessments is a governmental or industrial policy maker, a manager of exploration, a planner of regional development, or similar decision-maker. Some of the tools and models presented here will be useful for selection of exploration sites, but that is a side benefit, not the goal.

To provide unbiased information, we recommend the three-part form of mineral resource assessments where general locations of undiscovered deposits are delineated from a deposit type's geologic setting, frequency distributions of tonnages and grades of well-explored deposits serve as models of grades and tonnages of undiscovered deposits, and number of undiscovered deposits are estimated probabilistically by type. The internally consistent descriptive, grade and tonnage, deposit density, and economic models used in the design of the three-part form of assessments reduce the chances of biased estimates of the undiscovered resources.

What and why quantitative resource assessments: The kind of assessment recommended here is founded in decision analysis in order to provide a framework for making decisions concerning mineral resources under conditions of uncertainty. What this means is that we start with the question of what kinds of questions is the decision maker trying to resolve and what forms of information would aid in resolving these questions.

Some applications of mineral resource assessments: To plan and guide exploration programs, to assist in land use planning, to plan the location of infrastructure, to estimate mineral endowment, and to identify deposits that present special environmental challenges.

Why not just rank prospects / areas? Need for financial analysis, need for comparison with other land uses, need for comparison with distant tracts of land, need to know how uncertain the estimates are, need for consideration of economic and environmental consequences of possible development.

Our goal is to provide unbiased information useful to decision-makers. 
A short history: 1957 "Method of appraising economic prospects of mining exploration over large territories-Algerian Sahara case study" by M. Allais, 1974-75 beginning of three-part assessments in Alaska (Richter et al., 1975, Singer, 1975).

Three-part resource assessments: (1) General locations of undiscovered deposits are delineated from a deposit type's geologic setting, (2) Frequency distributions of tonnages and grades of well-explored deposits serve as models of grades and tonnages of undiscovered deposits, (3) Number of undiscovered deposits are estimated probabilistically by type.

The nature of mineral resources: Only a few deposits account for most resources, most important is tonnage — not grade in estimating total resources, few deposit types account for most resources.

\section{Required Deposit Models}

Integrated mineral deposit models are at the core of three-part assessments because they reduce uncertainty about locations, amounts, and values of resources.

General modeling: A model is a way in which the human thought process can be amplified. The way to describe a model is first by thinking about what it is for, about its function, not the list of items that make up its structure. What is surely needed as a minimum is an information system that will help the policy makers to make their decisions (Churchman, 1968). Desirable to define and use the same set of rules for all deposits in the model, these same set of rules apply to all of the undiscovered deposits that are estimated.

Descriptive models: Focus on observations, only use theories of origin to guide what to observe, observations must be available at scale of assessments.

Beginning of digital models: Documented and reproducible, do not miss the obvious and, can be used in classification and prediction.

Grade and tonnage models: The purpose of grade and tonnage models is to provide unbiased representations of the grades and tonnages of undiscovered mineral deposits in a tract or belt. Grade and tonnage models used in three-part assessments represent the premining grade and tonnage of a deposit. This means that current resources at the lowest cutoff grade are added to past production.

Grade and tonnage models use resource figures to represent the mineralized material in a deposit in order to allow for possibly different technologies and mining costs to be assumed.

Spatial rules for models: For deposit models, a spatial rule should be used to determine which ore bodies should be combined. For example, ore bodies of both kuroko and Cyprus type massive sulfides were combined into single deposits based on a 500-m rule of adjacency. Map scale affects what is called a mineral deposit, for some deposits legal or geographical boundaries affect what is reported as a deposit. 
Sources of errors in grade and tonnage models: Mixed geologic environments, poorly known geology, data recording errors, mixed deposit / district data, mixed mining methods, incomplete production / resource estimates.

Deposit density models: A robust method to estimate the number of undiscovered deposits is a form of mineral deposit model wherein numbers of deposits per unit area from well-explored regions are counted and the resulting frequency distribution is either used directly for an estimate or indirectly as a guideline in some other method. Although only three deposit types have detailed density models developed at this time, the combination of these studies with other density studies shows that the deposit density relationships can be generalized across deposit types (Singer, in press). The relationship between size of permissive tract and size of deposit estimated can be used to estimate the number of deposits for any deposit type.

Cost models: Models of capital and operating costs required to build and operate a mine and mill, and infrastructure that supports them. Models do not estimate costs of preproduction exploration, permitting, environmental studies, taxes, corporate overhead, site reclamation, concentrate transportation, or smelter and refinery charges. Although not all costs are included and the estimates are rough, these models serve to discriminate clearly uneconomic from clearly economic deposits at an early assessment stage. Daily capacity is the key variable in these models, mine life is calculated from capacity, capital and operating costs are a function of capacit, the equations vary with mining and milling methods.

\section{Delineation of Tracts and Estimating Number of Deposits}

We now can use geologic maps to divide a large region into parts that could contain different kinds of mineral deposist and we know that these different kinds of mineral deposits are significantly different in the amounts and qualities of minerals of interest to society. The differences in amounts and qualities of these kinds of deposits affect chances that the deposits will be sought, found, and exploited by society.

A brief overview of the supply and demand of mineral resources provides perspective to help understand why certain aspects of resources are of greater importance than others. In particular, we show that only certain kinds of deposits have dominated supply. In addition, only the largest deposits of a kind are important to global supply.

Mineral deposit models are at the core of three-part assessments. None of these models has any useful meaning except in the context of the other related models of the same deposit type. It should also not be forgotten that construction of these models is an iterative process. It is the internal consistency of these models that provides the strong foundation upon which unbiased assessments can be made - the same internal consistency means that much time-consuming work is required for their proper construction.

Mineral deposit models can be used to reduce uncertainty about locations, amounts, and values of the resources. Mineral deposit models are the keystone in combining the diverse geoscience information on geology, mineral occurrences, geophysics, and geochemistry used in resource assessments and mineral exploration. 
Principles of delineation: In order to be able to consistently assess undiscovered mineral resources of regions, areas are delineated where geology permits the existence of deposits of one or more specified types. Focus is on what types of deposits could be in the region rather than upon what types of deposits are known to occur.

Delineation of covered areas: The boundaries of mapped rock units form the primary basis for drawing boundaries of the tract. These preliminary tract boundaries should then be extended using geophysical surveys, such as aeromagnetics, to identify where permissive rocks are concealed by younger rocks or sediments.

An assessment: Pre-meeting: deposit typing, testing-building, delineation; discussion of ground rules, purpose, and goals; review geology, known deposits geophysics, geochemistry, and exploration history; review geologic settings of deposit type; delineate tracts permissive for deposit type; review grade and tonnage models and other appropriate guidelines; make estimates of number of undiscovered deposits; review estimates-revise if appropriate.

Estimating undiscovered mineral deposits: Estimates of number of deposits explicitly represent the probability (or degree of belief) that some fixed but unknown number of undiscovered deposits exist in the delineated tracts. As such, these estimates reflect both the uncertainty of what may exist and a measure of the favorability of the existence of the deposit type.

Guides for estimating number of deposits: Grade and tonnage model; deposit density models; statistical guides-coefficient of variation; counting and assigning probabilities to anomalies; process constraints; relative frequencies of related deposit types; area spatial limits; total known metal; exploration extent and efficiency.

Guidelines and some examples are provided to reduce biases in estimates of numbers of deposits. Experience from meteorology suggests that consensus schemes perform better than individual estimators and that the best estimates are made when objective estimates such as those from guidelines are part of the information supplied to subjective estimators (Murphy and Winkler, 1984).

Appropriate grade and tonnage model? It is sometimes believed that local deposits represent a special subtype or new type because they are almost never exactly the same as the "typical" deposit in every respect. Sometimes the global model is accepted without considering whether it is appropriate. There are two dangers in these two approaches: (1) Every deposit is considered to be unique and therefore prediction is not possible; (2) A new model may be necessary to provide unbiased estimates of grades and tonnages of the undiscovered deposits. To avoid both dangers, well-explored deposits that follow the spatial rules in the local area should be tested to see if they are statistically different from the general model ( $t$ test at the $1 \%$ level). Statistical tests are performed in order to help ensure that the grade and tonnage model selected will be representative of the grades and tonnages of the undiscovered deposits.

Biased estimates of number of deposits: There are estimation process issues that can point to bias such as the expert not following normative statistical or logical rules 
(Meyer and Booker, 2001). The most straightforward way to identify bias in estimates of number of deposits is to use the same tools that are available as guidelines for the estimates. Number of deposit estimates that are inconsistent with the guidelines should at the least raise questions about possible bias. Significant biases can be introduced by flawed grade and tonnage models, or by lack of consistency of estimated number of deposits with grade and tonnage model.

Example of estimation of number of deposits is provided.

\section{Combining Estimates and Economics}

Expected amounts of undiscovered metals can be estimated mathematically from the grade and tonnage models and estimates of number of deposits by making some assumptions.

A decision-maker needs to be keenly aware of the expected outcome and the probabilities of other outcomes.

A goal of three-part assessments: Provide decision-makers with unbiased information about the expected values and probabilities of other values/outcomes of undiscovered mineral resources. Expected values and probabilities of amounts of metals or economic value can be estimated via equations if certain assumptions are made.

The algorithms developed by Dave Root (Root et al., 1992) freed us from the assumptions of the Poisson and the lognormal distributions and provided distributionfree methods of calculating probabilities of number of deposits, tonnages, and quantities of contained metal in a Monte Carlo simulation in MARK3.

EMINERS, developed by Joe Duval (2001) used Root's algorithms and allowed adding new models by user and use of some economic filters.

Cost Models: Developed by USBM (Camm, 1991; Smith, 1992) based on detailed costing of 3-6 mines per mining/milling method. Tested and refined with general costs and mining rates from 10-40 mines per mining/milling method (Singer, Menzie, and Long, 1998, 2000; Long and Singer, 2001).

MARK3/EMINERS summary: For most models tested MARK3/EMINERS are able to capture the expected amounts and probabilities of different amounts of metal due to effects of estimated number of deposits, tonnages, and grades. For simplified cost models, work needs to be done to see that the proper mining methods are applied and the current costing algorithms are used.

Summary of quantitative mineral resource assessments:

What was covered: Quantitative resource assessment (3-part)

The nature of mineral resources

A short history

Mineral deposit models

Descriptive

Grade and tonnage 
Deposit density

Costs

Delineation and estimating number of undiscovered deposits

Combining grades, tonnages, number of deposits, and costs and summary

Three-part assessments are desirable because they: Respond to most customer needs, produce unbiased estimates, allow use of variety of information types, allow use of many methods, explicitly represent uncertainty, and are designed for economic analysis.

\section{References}

Anom., ed., 1998, Exploration models for major Australian mineral deposit types: AGSO Journal of Australian Geology \& Geophysics, v. 17, no. 4, p. 69-258.

Anom., translator, Cox, D.P., and Singer, D.A., eds., 1990, Mineral deposit models: USGS Bulletin 1693, 379 p. (in Chinese)

Allais, M., 1957, Method of appraising economic prospects of mining exploration over large territories-Algerian Sahara case study: Management Science, v. 3, no. 4, p. 285-347.

Barton, P.B., Jr, 1993, Problems and opportunities for mineral deposit models, in Kirkham, R.V., Sinclair, W.D., Thorpe, R.I., and Duke, J.M., eds., Mineral Deposit Modeling: Geological Association of Canada Special Paper 40, p. 7-13.

Blakely, R.J., 1996, Shallow magnetic lithologies as interpreted from low-altitude aeromagnetic data, in Singer, D.A., ed., An analysis of Nevada's metal-bearing mineral resources: Nevada Bureau of Mines and Geology Open-File Report 962, Chapter 3, 1 sheet, scale 1:1,000,000. (Also available at: http://www.nbmg.unr.edu/dox/ofr962/c3s.pdf (text) http://www.nbmg.unr.edu/dox/ofr962/plate312.pdf (plate)).

Bliss, J.D., ed., 1992, Developments in mineral deposit modeling: USGS Bulletin 2004, $168 \mathrm{p}$.

Camm, T.W., 1991, Simplified cost models for prefeasibility mineral evaluations: U.S. Bureau of Mines Information Circular 9298, 35 p.

Camm, T.W., 1994, Simplified cost models for prefeasibility mineral evaluations: Mining Engineering, v. 46, no. 6, June, p. 559-562.

Churchman, C. West, 1968, The Systems Approach: N.Y., Dell Publishing Co., 243 p.

Cox, D.P., ed., 1983, USGS-INGEOMINAS mineral resource assessment of Colombia: Ore deposit models: USGS Open-File Report83-423, 89 p.

Cox, D.P., ed., 1983, USGS-INGEOMINAS mineral resource assessment of Colombia: Additional ore deposit models: USGS Open-File Report 83-901, 25 p.

Cox, D.P., 1986, Descriptive model of porphyry Cu-Au deposits, in Cox, D.P., and Singer, D.A., eds., 1986, Mineral deposit models: U.S. Geological Survey Bulletin 1693, p. 110.

Cox, D.P., and Singer, D.A., eds., 1986, Mineral deposit models: U.S. Geological Survey Bulletin 1693, 379 p. 
Cox, D.P., Singer, D.A., and Rodriguez, E.A., eds., 1987, Modelos de yacimientos minerales: USGS Open-File Report 87-486, 514 p. (in spanish)

Cox, D.P., Berger, B.R., Ludington, Steve, Moring, B.C., Sherlock, M.G., Singer, D.A., and Tingley, J.V., 1996, Delineation of mineral resource assessment tracts and estimation of number of undiscovered deposits in Nevada, in Singer, D.A., ed., An analysis of Nevada's metal-bearing mineral resources: Nevada Bureau of Mines and Geology Open-File Report 96-2, Chapter 12, p. 12.1-12.25, 3 sheets, scale 1:1,000,000. (Also available at: http://www.nbmg.unr.edu/dox/ofr962/c12.pdf text) http://www.nbmg.unr.edu/dox/ofr962/plate121.pdf (plate 1) http://www.nbmg.unr.edu/dox/ofr962/plate122.pdf (plate 2) http://www.nbmg.unr.edu/dox/ofr962/plate123.pdf (plate 3))

Cunningham, C.G., Singer, D.A., Zappettini, E.O., Vivallo, S.W., Celada, C.M., Quispe, J., Briskey, J.A., Sutphin, D.M., Gajardo, M.M., Diaz, A., Portigiliati, C., Berger, V.I., Carrasco, R., and Schultz, K.J., 2007, A preliminary quantitative resource assessment of undiscovered porphyry copper resources in the Andes Mountains of South America: Soc. Economic Geology Newsletter, October 2007, no. 71, p. $1,8-13$.

Duval, J.S., 2001, A Microsoft Windows version of the MARK3 Monte Carlo mineral resource simulator: U.S. Geological Survey Open-File Report 00-415, 1 CDROM.

Ekstrand, O.R., Sinclair, W.D., and Thorpe, R.I., eds., 1995, Geology of Canadian mineral deposit types: Geological Survey of Canada, Geology of Canada, no. 8, and Geological Society of America's Geology of North America, v. P-1, 640 p.

Harris, DeVerle., Zucher, Lucas, Stanley, Michael, Marlow, Joesef, and Pan, Guocheng, 2003, A comparative analysis of favorability mapping by weights of evidence, probabilistic neural networks, discriminate analysis and logistic regression: Natural Resources Research, v. 12, no. 4, p. 241-255.

Grauch, V.J.S., 1996, Magnetically interpreted, granitoid plutonic bodies in Nevada, in Singer, D.A., ed., An analysis of Nevada's metal-bearing mineral resources: Nevada Bureau of Mines and Geology Open-File Report 96-2, Chapter 3, 1 sheet, scale 1:1,000,000. (Also available at: http://www.nbmg.unr.edu/dox/ofr962/plate712.pdf).

Jachens, R.C., Moring, B.C., and Schruben, P.G., 1996, Thickness of Cenozoic deposits and the isostatic residule gravity over basement; Nevada Bureau of Mines and Geology Open-File Report 96-2, Chapter 2, 22 p., 1 sheet, scale 1:1,000,000.

Koski, R.A., 1986, Descriptive model of volcanogenic Mn deposits, in Cox, D.P., and Singer, D.A., eds., Mineral deposit models: U.S. Geological Survey Bulletin 1693, p. 139.

Lisitsin, V., Olshina, A., Moore, D.H., and Willman, C.E., 2007, Assessment of undiscovered mesozonal orogenic gold endowment under cover in the northern part of the Bendigo Zone: GeoScience Victoria Gold Undercover Report 2, Department of Primary Industries, 98 p. [http://www.dpi.vic.gov.au/minpet/store] 
Long, Keith R., and Singer, D.A., 2001, A simplified economic filter for open-pit mining and heap-leach recovery of copper in the United States; U.S. Geological Survey Open-file Report 01-218, 21p. (http://geopubs.wr.usgs.gov/open-file/of01-218/)

Ludington, Steve, Cox, D.P., Leonard, K.W., and Moring, B.C., 1996, Cenozoic Volcanic geology of Nevada, in Singer, D.A., ed., An analysis of Nevada's metal-bearing mineral resources: Nevada Bureau of Mines and Geology OpenFile Report 96-2, Chapter 5, 1 sheet, scale 1:1,000,000. (Also available at: http://www.nbmg.unr.edu/dox/ofr962/c5.pdf (text) http://www.nbmg.unr.edu/dox/ofr962/plate512.pdf (plate)).

Ludington, Steve, McKee, E.H. Cox, D.P., Moring, B.C., and Leonard, K.R., 1996, PreTertiary geology of Nevada, in Singer, D.A., ed., An analysis of Nevada's metalbearing mineral resources: Nevada Bureau of Mines and Geology Open-File Report 96-2, Chapter 4, 1 sheet, scale 1:1,000,000. (Also available at: http://www.nbmg.unr.edu/dox/ofr962/c4.pdf (text) http://www.nbmg.unr.edu/dox/ofr962/plate412.pdf (plate)).

Menzie, David, Foose, Michael, Schulz, Klaus, and Lampietti, Francois, 2005, A shortcourse on methodologies for the assessment of undiscovered mineral resources: U.S. Geological Survey Open-File Report 2005-1146 (published as a CD-ROM).

Meyer, M.A., and Booker, J.M., 2001, Eliciting and analyzing expert judgment: A practical guide: Philadelphia, American Statistical Association and Society for Industrial and Applied Mathematics, $459 \mathrm{p}$.

Mosier, D.L., and Page, N.J, 1988, Descriptive and grade-tonnage models of volcanogenic manganese deposits in ocean environments-a modification: U.S. Geological Survey Bulletin 1811, 28 p.

Mosier, D.L., Singer, D.A., and Berger, V.I., 2007, Volcanogenic massive sulfide deposit density: U.S. Geological Survey Scientific Investigations Report 20075082, 21 p. [http://pubs.usgs.gov/sir/2007/5082/]

Mosier, D.L., Singer, D.A., and Salem, B.B., 1983, Geologic and grade-tonnage information on volcanic-hosted copper-zinc-lead massive sulfide deposits: U.S. Geological Survey Open-File Report 83-89, 78 p.

Murphy, A.H., and Winkler, R.L., 1984, Probability forecasting in meteorology: Journal American Statistical Association, v. 79, no. 387, p. 489-500.

Orris, G.J., and Bliss, J.D., eds., 1991, Some industrial mineral deposit modelsdescriptive deposit models: USGS Open-File Report 91-11A, 73 p.

Orris, G.J., and Bliss, J.D., eds., 1992, Industrial mineral deposit models: Grade and tonnage deposit: USGS Open-File Report 92-437, 84 p.

Raines, G.L., and Mihalasky, M.J., 2004, A reconnaissance method for delineation of tracts for regional-scale mineral resource assessment based on geologic-map data: Natural Resources Research, v. 11, no. 4, p. 241-248.

Reed, B.L., Menzie, W.D., McDermott, M., Root, D.H., Scott, W., 1989, Undiscovered lode tin resources of the Seward Peninsula, Alaska: Economic Geology, v. 84, no. 7, p. 1936-1947. 
Richter, D.H., Singer, D.A., and Cox, D.P., 1975, Mineral resource map of the Nabesna Quadrangle, Alaska: U.S. Geological Survey Miscellaneous Field Studies Map MF-655K, 1 sheet, scale 1:250,000, (interpretative text).

Roberts, R.G., and Sheahan, P.A., eds., 1988, Ore deposit models: Geoscience Canada Reprint Series 3, 200 p.

Rogers, M.C., Thurston, P.C., Fyon, J.A., Kelly, R.I., and Breaks, R.W., 1995, Descriptive mineral deposit models of metallic and industrial deposit types and related mineral potential assessment criteria: Ontario Geological Survey OpenFile Report 5916, 241 p.

Rongfu, Pei, ed., 1995, Mineral deposits models of China: Geological Publishing House, Beijing, $357 \mathrm{p}$.

Root, D.H., Menzie, W.D., and Scott, W.A., 1992, Computer Monte Carlo simulation in quantitative resource estimation: Nonrenewable Resources, v. 1, no. 2, p. 125138.

Sheahan, P.A., and Cherry, M.E., eds., 1993, Ore deposit models, volume II: Geoscience Canada Reprint Series 6, 160 p.

Sherlock, M.G., Cox, D.P., and Huber, D.F., 1996, Known deposits and occurrences in Nevada, in Singer, D.A., ed., An analysis of Nevada's metal-bearing mineral resources: Nevada Bureau of Mines and Geology Open-File Report 96-2, Chapter 10, 2 sheets, scale 1:1,000,000. (Also available at: http://www.nbmg.unr.edu/dox/ofr962/c10.pdf (text) http://www.nbmg.unr.edu/dox/ofr962/plate101.pdf (plate 1) http://www.nbmg.unr.edu/dox/ofr962/plate102.pdf (plate 2))

Singer, D.A., 1975, Mineral resource models and the Alaskan Mineral Resource Assessment Program, in Vogely, W.A., ed., Mineral Materials Modeling: A State-of-the Art Review: Baltimore, Johns Hopkins Univ. Press, p. 370-382.

Singer, D.A., 1993, Basic concepts in three-part quantitative assessments of undiscovered mineral resources: Nonrenewable Resources, v. 2, no. 2, p. 69-81.

Singer, D.A., 1993, Development of grade and tonnage models for different deposit types, in Kirkham, R.V., Sinclair, W.D., Thorpe, R.I., and Duke, J.M., eds., Mineral deposit modeling: Geological Association Canada Special Paper 40, p. 21-30.

Singer, D.A., 1994, Conditional estimates of the number of podiform chromite deposits: Nonrenewable Resources, v. 3, no. 3, p. 200-204.

Singer, D.A., 1995, World-class base and precious metal deposits-a quantitative analysis: Economic Geology, v. 90, no. 1, p. 88-104.

Singer, D.A., 1996, Grade and tonnage models, in Singer, D.A., ed., An analysis of Nevada's metal-bearing mineral resources: Nevada Bureau of Mines and Geology Open-File Report 96-2, Chapter 11, p. 11.1-11.18. (Also available at: http://www.nbmg.unr.edu/dox/ofr962/c11.pdf).

Singer, D.A., 2007, Estimating amounts of undiscovered mineral resources, in Briskey, J.A., and Schulz, K.J., eds., Proceedings for a Workshop on Deposit Modeling, Mineral Resources Assessment, and Their Role in Sustainable Development: 
U.S. Geological Survey Circular 1294, p. 79-84. (Also available online at http://pubs.usgs.gov/circ/2007/1294/).

Singer, D.A., in press, Mineral deposit densities for estimating mineral resources: Mathematical Geosciences, v. 40, no. 1, 17 p.

Singer, D.A., and Berger, Vladimir, 2007, Deposit models and their application in mineral resource assessments, in Briskey, J.A., and Schulz, K.J., eds., Proceedings for a Workshop on Deposit Modeling, Mineral Resources Assessment, and Their Role in Sustainable Development: U.S. Geological Survey Circular 1294, p. 71-78. (Also available online at http://pubs.usgs.gov/circ/2007/1294/).

Singer, D.A., and Kouda, Ryoichi, 1999, Examining risk in mineral exploration: Natural Resources Research, v. 8, no. 2, p. 111-122.

Singer, D.A., and Kouda, Ryoichi, 1997, Use of a neural network to integrate geoscience information in the classification of mineral deposits and occurrences, in Gubins, A.G., ed., Proceedings of Exploration 97-Fourth Decennial International Conference on Mineral Exploration: p. 127-134.

Singer, D.A., and Menzie, W.D., 2005, Statistical guides to estimating the number of undiscovered mineral deposits: an example with porphyry copper deposits, in Cheng, Qiuming and Bonham-Carter, Graeme, eds., Proceedings of IAMG-The annual conference of the International Assoc. for Mathematical Geology: Geomatics Research Laboratory, York University, Toronto, Canada, p. 10281033.

Singer, D.A., and Menzie, W.D., in press, Map scale effects on estimating the number of undiscovered mineral deposits, in Qiuming Cheng and Graeme Bonham-Carter, eds., 40 Years Progress in Mathematical Geology: Elsevier, 19 p.

Singer, D.A., and Ovenshine, A.T., 1979, Assessing metallic mineral resources in Alaska: American Scientist, v. 67, no. 5, p. 582-589. (republished in Skinner, B.J., ed., 1980, Earth's Energy and Mineral Resources, William Kaufman, Inc., p. 170-177).

Singer, D.A., Berger, V.I., and Moring, B.C., 2005, Porphyry copper deposits of the world: database, map, and grade and tonnage models: U.S. Geological Survey Open-File Report 2005-1060, http://pubs.usgs.gov/of/2005/1060/).

Singer, D.A., Menzie, W.D., and Long, K.R., 1998, A simplified economic filter for open-pit gold-silver mining in the United States: U. S. Geological Survey OpenFile Report 98-207, 10 p. (http://geopubs.wr.usgs.gov/open-file/of98-207/).

Singer, D.A., Menzie, W.D., and Long, K.R., 2000, A simplified economic filter for underground mining of massive sulfide deposits; U.S. Geological Survey OpenFile Report 00-349, 20 p.

Singer, D.A., Mosier, D.L., and Cox, D.P., 1986, Grade and tonnage model of porphyry copper deposits, in Cox, D.P. and Singer, D.A., eds., Mineral deposit models: U.S. Geological Survey Bulletin 1693, p. 77-81.

Singer, D.A., Mosier, D.L., and Menzie, W.D., 1993, Digital grade and tonnage data for 50 types of mineral deposits-Macintosh version: U.S. Geological Survey OpenFile Report 93-280, 1 disk, 52 files. 
Singer, D.A., Berger, V.I., Menzie, W.D., and Berger, B.R., 2005, Porphyry copper density: Economic Geology, v. 100, no. 3, p. 491-514.

Singer, D.A., Menzie, W.D., Sutphin, David, Mosier, D.L., and Bliss, J.D., 2001, Mineral deposit density - an update, in Schulz, K.J., ed., Contributions to global mineral resource assessment research: U.S. Geological Survey Professional Paper 1640-A, p. A1-A13. (Also available online at http://pubs.usgs.gov/pp/p1640a/).

Singer, D.A., Page, N.J, Smith, J.G., Blakely, R.J., and Johnson, M.G., 1983, Mineral resource assessment of the Medford $1^{\circ}$ x $2^{\circ}$ Quadrangle, Oregon-California: U.S. Geological Survey Miscellaneous Field Studies Map MF-1383-E, 2 sheets, scale 1:250,000. (also published as: U.S. Geological Survey Open-File Report 82-1037, 2 sheets, 28 p.) (interpretative text)

Singer, D.A., Page, N.J, Bagby, W.C., Cox, D.P., and Ludington, Steve, 1987, Assessment on metallic mineral resources of Costa Rica, in United States Geological Survey, Direccion General de Geologia, Minas e Hidrocarburos, and Universidad de Costa Rica, 1987, A mineral resource assessment of the Republic of Costa Rica: U.S. Geological Survey Miscellaneous Investigations Series Map I-1865, scale 1:500,000, p. 58-64. (interpretative text)

Smith, R.C., 1992, PREVAL-Prefeasibility software program for evaluating mineral deposits: U.S. Bureau of Mines Information Circular 9307, 35 p.

Tanimura, S., et al, 1983, Part II. Stratigraphy and structure of the Hokuroku District, in Omoto, Hiroshi, and Skinner, B.J., eds., The kuroko and related volcanogenic massive sulfide deposits: Economic Geology Monograph 5, p. 24-54.

Taylor, H.K., 1985, Cutoff grades—some further reflections: Transactions Institution of Mining and Metallurgy (Section A: Mining Industry), v. 94, p. A204-A216.

Theodore, T.G., Orris, G.A., Hammarstrom, J.M., and Bliss, J.D., 1991, Gold-bearing skarns: U.S. Geological Survey Bulletin 1930, 61 p.

U.S. Bureau of Miners and U.S. Geological Survey, 1980, Principles of reserve/resource classification for minerals: U.S. Geological Survey Circular 831, 5 p.

U.S. Geological Survey Minerals Team, 1996, Data base for a National mineral-resource assessment of undiscovered deposits of gold, silver, copper, lead, and zinc in the conterminous United States: U.S. Geological Survey Open-File Report 96-96.

Wilson, F.H., White, W.H., Detterman, R.L., and Case, J.E., 1996, Maps showing the resource assessment of the Port Moller, Stepovak Bay, and Simeonof Island Quadrangles, Alaska Peninsula: U.S. Geological Survey MF 2155-F, 3 pieces, scale 1:250,000. 